\title{
$\mathrm{Sn}-4.0 \mathrm{wt} \% \mathrm{Ag}-0.5 \mathrm{wt} \% \mathrm{Cu}$ 솔더 접합계면의 강도특성과 미세파괴거동에 대한 In-situ관찰
}

\author{
이경근 · 최은근 · 추용호* · 김진수 · 이병수 · 안행근 \\ 전북대학교 공과대학 신소재공학부 \\ *전북대학교 신소재개발연구센터
}

\section{In-situ Observation on Micro-Fractural Behavior and Strength Characteristics in Sn-4.0wt\%Ag-0.5wt\%Cu Solder Joint Interface}

\author{
Kyung-Keun Lee, Eun-Geun Choi, Yong-Ho Chu*, Jin-Soo Kim, Byung-Soo Lee and Haeng-Keun Ahn \\ School of Advanced Materials Engineering, Chonbuk National Univerisity, Jeonju, Jeonbuk 561-756, Korea \\ *Research Institue of Advanced Materials Development, Chonbuk National Univerisity
}

(2007년 12월 14일 접수 : 2007년 12월 27일 채택)

\begin{abstract}
The micro-structural changes, strength characteristics, and micro-fractural behaviors at the joint interface between a Sn-4.0wt\%Ag-0.5wt\% Cu solder ball and UBM treated by isothermal aging are reported. From the reflow process for the joint interface, a small amount of intermetallic compound was formed. With an increase in the isothermal aging time, the type and amount of the intermetallic compound changed. The interface without an isothermal treatment showed a ductile fracture. However, with an increase in the aging time, a brittle fracture occurred on the interface due mainly to the increase in the size of the intermetallic compounds and voids. As a result, a drastic degradation in the shear strength was observed. From a microshear test by a scanning electron microscope, the generation of micro-cracks was initiated from the voids at the joint interface. They propagated along the same interface, resulting in coalescence with neighboring cracks into larger cracks. With an increase in the aging time, the generation of the micro-structural cracks was enhanced and the degree of propagation also accelerated.
\end{abstract}

Key words BGA solder ball, solder joint interface, intermetallic compound(IMC), micro-fracture behavior, in-situ observation.

\section{1. 서 론}

정보통신산업이 급속도로 발전함에 따라 반도체 부품 소자의 고집적화, 고성능화 및 경박 단소화가 이루어지 면서 반도체 패키징 기술 또한 보다 높은 정밀도가 요 구되고 있다. 특히 휴대폰과 같은 통신기기의 소형화 경 향은 기존보다 더 작은 솔더 볼을 사용할 수 밖에 없 게 되었다. ${ }^{1)}$ 그러나, 작은 솔더볼의 적용은 단위 부피당 열방출 양이 증가하여 솔더 접합부의 신뢰성을 저하시키 게 된다. 이들 작은 솔더 접합부는 소자의 사용 중 지 속적인 전기적 $\mathrm{On} / \mathrm{Off}$ 와 열방출 불량으로 야기되는 열 시효 및 열피로에 의해 미세조직이 변화하여 불균일 조 대화 및 성분원소의 분리가 나타나고, 솔더와 UBM(under bump metallurgy) 사이에서는 성분원소의 확산 및 계면 반응에 의해 금속간화합물(intermetallic compound, IMC)

Corresponding author

E-Mail : ahnhk@chonbuk.ac.kr (H. - K. Ahn)
이 생성되어 성장하게 된다. 이러한 미세조직의 변화에 의해 접합강도가 감소하여 솔더 접합부는 물론 패키지의 역학적 신뢰성이 감소하는 문제가 발생하게 된다. ${ }^{2-6)}$

한편, 솔더볼 소재의 적용에 있어서는, 근래에 이르기 까지 $\mathrm{Sn}-\mathrm{Pb}$ 계 합금이 유용한 솔더재료로 많이 사용되어 왔으나 $\mathrm{Pb}$ 는 환경오염과 인체에 치명적인 손상을 끼치 므로 $\mathrm{Sn}-\mathrm{Pb}$ 계 합금을 대체할 $\mathrm{Pb}$-free 솔더재료의 연구개 발 및 응용이 급속도로 진행되고 있다. ${ }^{7-10)}$ 새롭게 개발 되어 실용되고 있는 $\mathrm{Pb}-\mathrm{free}$ 솔더 합금의 일종인 $\mathrm{Sn}-\mathrm{Ag}$ 솔더의 접합부에서는 $\mathrm{Sn}-\mathrm{Pb}$ 계열의 솔더 접합부와는 달 리 금속간화합물의 생성에 의한 취성파괴 사례가 다수 보 고되고 있다. ${ }^{1,2,5,11)}$

이종재료의 복합구조로 이루어진 반도체 소자의 파괴 특성은 솔더볼의 재질, $\mathrm{UBM}$ 구조 및 두께, 시효온도 등 에 따라 다르게 나타난다. ${ }^{3,4)}$ 응력의 특성 및 크기는 이 종재료간의 제조 시 성장하는 재료의 결정립계 상호작용 등 재료의 미세구조와 깊은 연관성을 가지고 있으며, 응 
력은 이종재료간의 열팽창계수차이에 의해 기기의 작동 중 전류 등의 원인으로 생기는 열로 인하여 발생한다. ${ }^{11)}$ 이러한 열응력은 반도체칩 및 패키지에서 균열 또는 박 리 등의 파손현상을 발생시키며 내부회로의 단락을 가속 화시킨다. 금속-금속 접합인 솔더 접합부에서는 전기적 효 과에 의한 electro migration 보다는 열적확산에 의해 생 성되는 금속간화합물이 파괴특성에 주도적인 역할을 하 는 것으로 알려져 있다. ${ }^{12,13)}$

이와 같은 배경하에서, 본 연구에서는 크기가 각각 직 경 $630 \mu \mathrm{m}$, 직경 $300 \mu \mathrm{m}$ 인 $\mathrm{BGA}$ (ball grid array) 무연솔더 $\mathrm{Sn}-4.0 \mathrm{wt} \% \mathrm{Ag}-0.5 \mathrm{wt} \% \mathrm{Cu}$ 합금을 솔더재료로 선택하고, 이 것에 여러 가지 조건으로 인위적인 열이력(온도, 시간)을 가한 다음, 열이력에 따른 솔더/UBM 접합계면의 미세 조직변화를 조사하고, 미세조직변화와 접합강도의 상호 연 관성, 열영향에 의한 접합부의 열화 정도를 평가하였다. 또한, SEM(scanning electron microscope, Jeol JSM 5900) 내에서 미소전단/굽힘시험장치(micro tensile and bending stage for SEM, Debon co.)를 이용하여 열이력에 따른 $\mathrm{BGA}$ 솔더/UBM 접합계면의 균열발생 및 균열전파 등 미세파괴양상을 실시간으로 관찰함으로써 $\mathrm{BGA}$ 솔더볼의 파괴거동을 규명하고, 전자패키지의 기계적 신뢰성 평가 와 그 개선을 위한 기초자료를 제시하고자 하였다.

\section{2. 실험 방법}

본 연구에 사용된 시료는 2 개의 서로 다른 크기의 $\mathrm{Sn}-$ $4.0 \mathrm{wt} \% \mathrm{Ag}-0.5 \mathrm{wt} \% \mathrm{Cu}$ 합금 솔더볼로써 그 크기, substrate 와 $\mathrm{UBM}$ 의 종류 및 두께는 Table 1 과 같다.

Table 1의 시험편 제조(솔더링 공정)는 크게 5가지 단 계로 나누어서 수행하였다. 우선 기지금속 $(\mathrm{pad})$ 은 $\mathrm{Cu}$ 로 하였으며, 이 $\mathrm{Cu}$ 패드 위에 전기도금하여 $\mathrm{Ni}$ 박막(UBM) 을 입혔다. 그 위에 두께 $30 \mu \mathrm{m} \sim 50 \mu \mathrm{m}$ 의 후막 photo $\operatorname{resist}(\mathrm{PR})$ 를 코팅한 다음, $\mathrm{Sn}-4.0 \mathrm{wt} \% \mathrm{Ag}-0.5 \mathrm{wt} \% \mathrm{Cu}$ 솔더 재료를 전기도금 하였다. PR strip 및 $\mathrm{UBM}$ 층을 에칭하 고 reflow에 의해 솔더링 하였다. 솔더링에 사용된 리플 로우 장비는 적외선·열풍혼합방식으로, 전체 리플로우 시간은 5 분이고 컨베이어 속도는 $0.6 \mathrm{~m} / \mathrm{min}$ 였다. 솔더의 최고온도 설정은 용융온도 $\left(217^{\circ} \mathrm{C}\right)$ 를 고려하여 $225^{\circ} \mathrm{C}$ 로 하 였으며, 솔더의 액상유지시간은 1 분으로 하였다. 직경

Table 1. Details of the samples.

\begin{tabular}{ccccc}
\hline \hline Material & $\begin{array}{c}\text { Ball } \\
\text { diameter } \\
(\mu \mathrm{m})\end{array}$ & $\begin{array}{c}\text { Substrate } \\
\text { thickness } \\
\text { FR-4(mm) }\end{array}$ & $\begin{array}{c}\mathrm{Pad}(\mathrm{Cu}) \\
(\mu \mathrm{m})\end{array}$ & $\begin{array}{c}\mathrm{UBM}(\mathrm{Ni}) \\
(\mu)\end{array}$ \\
\hline $\begin{array}{c}\text { Sn-4.0wt\%Ag- } \\
0.5 \mathrm{wt} \% \mathrm{Cu}\end{array}$ & 630 & 0.6 & 30 & 8 \\
\hline
\end{tabular}

$630 \mu \mathrm{m}$ 의 경우, 패시베이션의 개구 크기는 약 $450 \mu \mathrm{m}$, $\mathrm{UBM}$ size는 $410 \mu \mathrm{m}$ 로 고정하였으며, 이때 시편의 크기 는 $21 \mathrm{~mm} \times 21 \mathrm{~mm}$ 였다. 직경 $300 \mu \mathrm{m}$ 의 경우는 패시베이 션의 개구 크기를 약 $200 \mu \mathrm{m}, \mathrm{UBM}$ size는 $180 \mu \mathrm{m}$ 로 고 정하였다. 이때 시편의 크기는 $13.03 \mathrm{~mm} \times 13.03 \mathrm{~mm}$ 였다.

인위적으로 열이력을 부여하기 위한 시효처리는 thermal tube furnace(Lenton Co, LTF-15/50/450)를 이용하였고, 대기 중에서 시효온도는 $175^{\circ} \mathrm{C}$, 시효시간은 $0 \mathrm{hr} 800 \mathrm{hr}$ 범위 였다. 솔더볼/UBM 접합계면사이에 형성되는 금속 간화합물 층에서의 전단강도를 측정하기 위하여 $\mathrm{ball}$ shear tester(Royce Co. system 522)를 사용하였으며, 팁 의 이동속도 $300 \mu \mathrm{m} / \mathrm{sec}$, 기판과 팁 사이의 거리 $30 \mu \mathrm{m}$, load testing module range $5 \mathrm{~kg}$ 으로 하여 시험하였다. 시효 처리한 시편은 세척 후 건조하고 경면연마 한 후, SEM (JEOL, JSM-6300)과 에너지분산회절법(EDX, energy dispersive diffractometery)을 이용하여 열시효 시간에 따 른 솔더볼/UBM 접합계면의 미세조직 및 상을 분석하였다.

SEM 내에서의 in-situ 미세전단시험은 SEM용 미소인 장/굽힘시험장치를 사용하였으며, 그 개관을 Fig. 1에 나 타내었다. SEM용 미소전단/굽힘시험장치를 SEM 내부에 장착하고 e-beam 조사하에서 전단시험하는 중에 솔더볼 $/ \mathrm{UBM}$ 계면에서의 크랙발생과 전파, 파단거동을 실시간 관찰하였다. 미세전단시험용 시편은 $5.0 \mathrm{~mm}(\mathrm{H}) \times 10 \mathrm{~mm}(\mathrm{~L})$ $\times 0.9 \sim 1.2 \mathrm{~mm}(\mathrm{~T})$ 의 크기로 제작하였으며, 시편지지대에 거 치한 후 클램프로 고정시켰다. 기판으로부터 전단 팁까 지의 높이는 약 15-20 $\mu \mathrm{m}$ 정도로 유지하였고, 전단부하시 변위속도는 $0.5 \mu \mathrm{m} / \mathrm{sec}$ 로 하였다. 변위량은 팁이 솔더볼 에 닿았을 때를 loading force가 증가되기 시작하는 초 기값으로 잡아 기록된 변위를 측정하여 계산하였다.

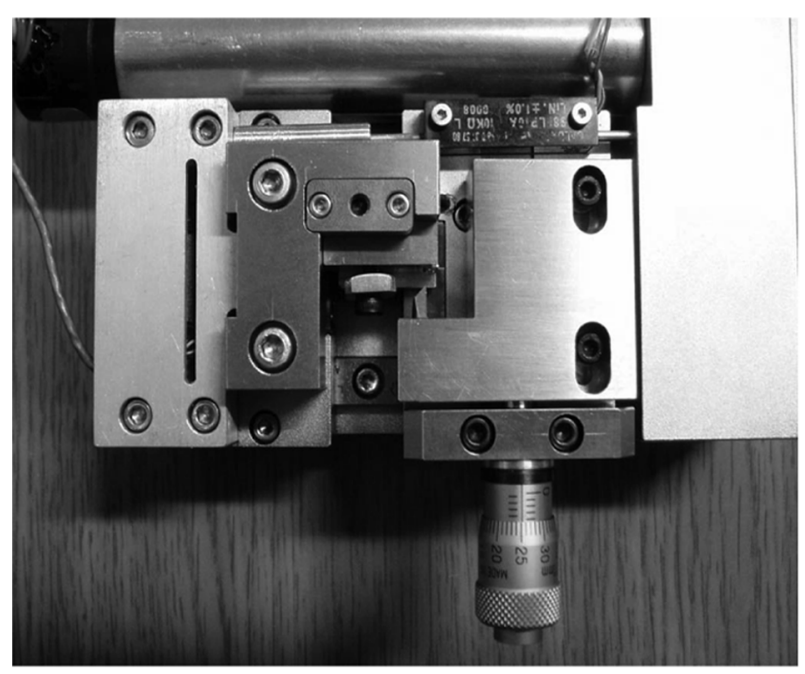

Fig. 1. A micro-shear tester in a SEM for in-situ observation. 


\section{3. 결과 및 고찰}

솔더/UBM 접합계면에서 금속간화합물의 형성은 UBM 의 종류, 시효시간, solder 재료 및 크기 등에 따라 다 양한 특성을 나타낸다. ${ }^{14)}$ 본 연구에서는 먼저 열시효에 따른 솔더/UBM 접합계면에서의 금속간화합물의 형성 및 성장거동을 관찰하고, 금속간화합물의 성장에 따른 솔더 볼 접합부의 강도특성과 파괴거동을 조사하였다.

Fig. 2는 시효시간에 따른 $\mathrm{Sn}-4.0 \mathrm{wt} \% \mathrm{Ag}-0.5 \mathrm{wt} \% \mathrm{Cu}$ (직 경 $630 \mu \mathrm{m})$ 솔더볼/UBM 계면부위의 단면 $\mathrm{SEM}$ 사진이 다. 솔더계면에 대한 $\mathrm{EDX}$ 분석 결과, 모든 시편에서 계 면에 금속간화합물 층이 형성된 것을 확인할 수 있었다. 시효처리하지 않은 시편의 경우는 $\mathrm{Ni}_{3} \mathrm{Sn}_{4}$ 상이, 시효시 간이 $100 \mathrm{hr}$ 이상인 시편에서는 $(\mathrm{Cu}, \mathrm{Ni})_{6} \mathrm{Sn}_{5}$ 상이 형성되 어 있었다. 시효처리 하지 않은 경우의 $\mathrm{Ni}_{3} \mathrm{Sn}_{4}$ 상은 리 플로우 공정에서 형성된 것으로 보이며, ${ }^{1)}$ 시효시간이 $100 \mathrm{hr}$ 이상인 시편에서의 $(\mathrm{Cu}, \mathrm{Ni})_{6} \mathrm{Sn}_{5}$ 상은 시효시간이 증가함에 따라 이미 형성되어 있는 $\mathrm{Ni}_{3} \mathrm{Sn}_{4}$ 상 쪽으로 $\mathrm{Cu}$ 가 확산함으로서 $(\mathrm{Cu}, \mathrm{Ni})_{6} \mathrm{Sn}_{5}$ 상으로 변태되어 형성되는
것으로 생각된다 ${ }^{2)}$ 또한, 솔더내부는 시효처리를 하지 않

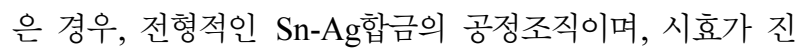
행됨에 따라 이 공정조직의 결정립이 성장하고 $\mathrm{Ag}_{3} \mathrm{Sn}$ 금 속간화합물이 조대화하는 경향이 나타나고 있다. 솔더 접 합계면에서는 시효초기에 나타나기 시작한 void가 시효 시간이 증가함에 따라 점차적으로 커지는 양상이 관찰되 고 있다. 이는 고온의 열시효에 의해 결정립 조대화가 일 어나고 열응력이 발생하는 것에 따른 것으로 생각된다.

Fig. 3은 시효시간에 따른 $\mathrm{Sn}-4.0 \mathrm{wt} \% \mathrm{Ag}-0.5 \mathrm{wt} \% \mathrm{Cu}($ 직 경 $300 \mu \mathrm{m}$ ) 솔더볼/UBM 계면부위의 단면 SEM 사진이 다. 모든 시편에서 계면에 금속간화합물 층이 형성된 것 을 확인할 수 있었다. 시효처리하지 않은 시편의 경우는 $(\mathrm{Cu}, \mathrm{Ni})_{6} \mathrm{Sn}_{5}$ 상이 형성되어 있음을 관찰할 수 있으며, 시 효시간이 증가함에 따라 $\mathrm{Cu}_{6} \mathrm{Sn}_{5}$ 상과 $\mathrm{Cu}_{3} \mathrm{Sn}$ 상이 2층으 로 형성되어 있었다. 솔더볼 직경 $630 \mu \mathrm{m}$ 경우와는 미세 조직의 변화양상이 매우 다른데, 이것은 솔더볼의 크기 에 따라 큰 차이가 있음을 보여주고 있다. 솔더볼의 크 기가 직경 $300 \mu \mathrm{m}$ 정도로 작은 경우, 리플로우 공정에서 $\mathrm{Cu}$ 패드와 $\mathrm{UBM}(\mathrm{Ni}$ 박막) 사에에 이미 $\mathrm{Cu}$ 의 확산이 상당

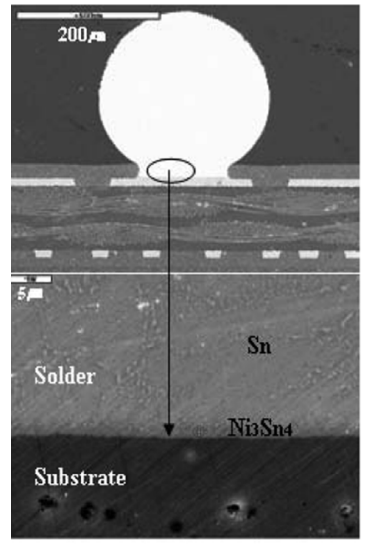

(a) No aging

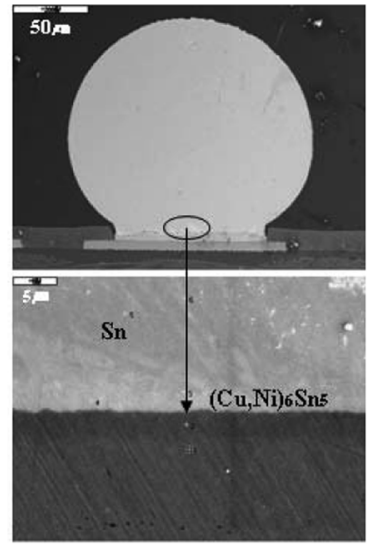

(b) $100 \mathrm{hr}$

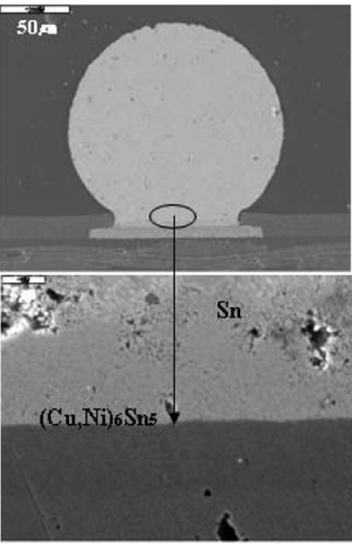

(c) $200 \mathrm{hr}$

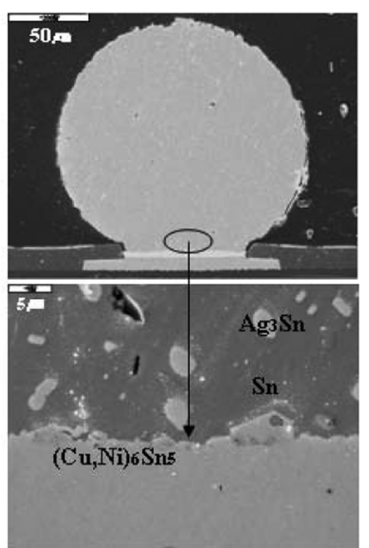

(d) $400 \mathrm{hr}$
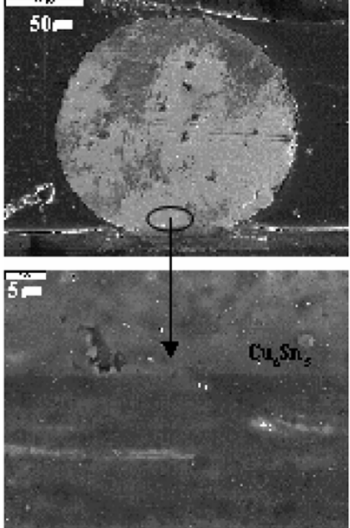

(e) $800 \mathrm{hr}$

Fig. 2. Cross sectional images for the interface between the $\mathrm{Sn}-4.0 \mathrm{wt} \% \mathrm{Ag}-0.5 \mathrm{wt} \% \mathrm{Cu}(\phi 630 \mu \mathrm{m})$ solder ball and substrate under the various aging times. 


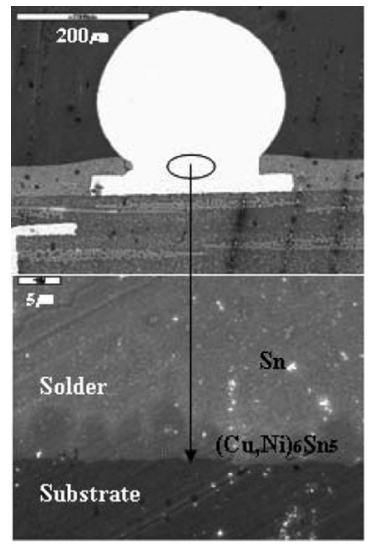

(a) No aging
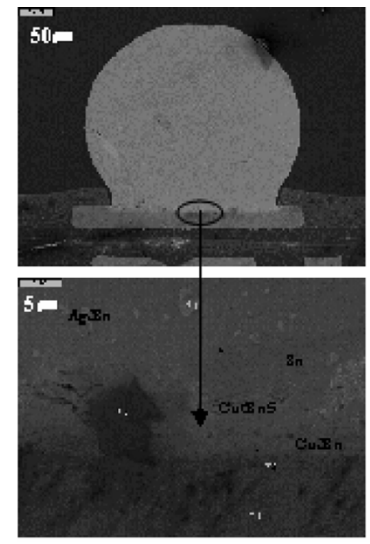

(b) $100 \mathrm{hr}$
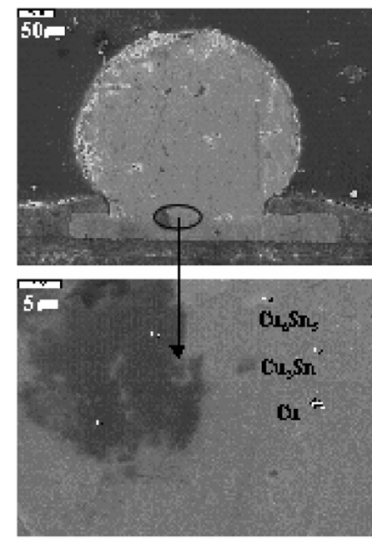

(c) $200 \mathrm{hr}$

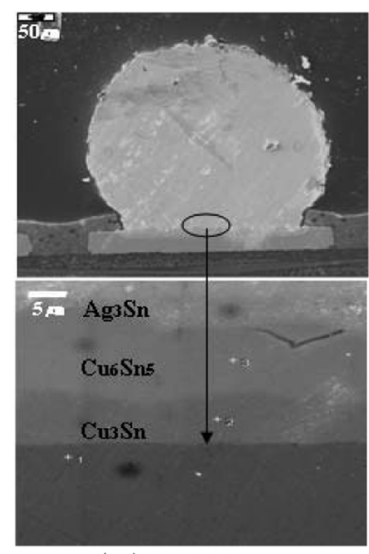

(d) $400 \mathrm{hr}$
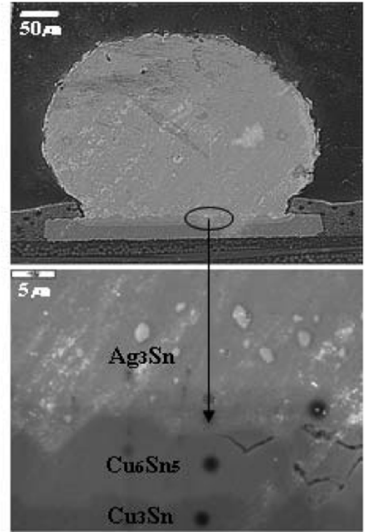

(e) $800 \mathrm{hr}$

Fig. 3. Cross sectional images for the interface between the $\mathrm{Sn}-4.0 \mathrm{wt} \% \mathrm{Ag}-0.5 \mathrm{wt} \% \mathrm{Cu}(\phi 300 \mu \mathrm{m})$ solder ball and substrate under the various aging times.

량 진행되어 $(\mathrm{Cu}, \mathrm{Ni})_{6} \mathrm{Sn}_{5}$ 상이 형성된 것으로 보이며, 시 효시간이 증가함에 따라 접합계면에 비교적 고온상태에 서나 관찰되는 $\mathrm{Cu}_{3} \mathrm{Sn}$ 상이 출현하였다. Chen and $\mathrm{Lin}$ 의 ${ }^{15}$ 보고에 따르면, 솔더와 $\mathrm{Cu}$ 패드의 계면에서 금속간화합물 은 $\mathrm{Cu}_{3} \mathrm{Sn}$ 상 보다 $\mathrm{Cu}_{6} \mathrm{Sn}_{5}$ 상의 성장이 훨씬 빠르기 때문 에 $\mathrm{Cu}_{6} \mathrm{Sn}_{5}$ 상만이 관찰되고, 고온에서 장시간 열처리를 할 경우는 $\mathrm{Cu}_{3} \mathrm{Sn}$ 상이 $\mathrm{SEM}$ 에서 관찰 된다고 하였다. 또한 , 일반적으로 $\mathrm{Cu}_{3} \mathrm{Sn}$ 상은 $\mathrm{Cu}_{6} \mathrm{Sn}_{5}$ 상이 소멸되면서 발생하 며, $\mathrm{Ni}$ 을 함유하는 복합솔더에서는 $\mathrm{Ni}$ 의 barrier효과에 의

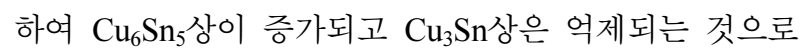
알려져 있다. ${ }^{2)}$ 본 연구에서 검토한 결과와 이들의 연구 결과는 대략 일치하고 있는 것을 알 수 있다. 솔더내부 에서는 시효처리를 하지 않은 경우, 전형적인 $\mathrm{Sn}-\mathrm{Ag}$ 합 금의 공정조직을 관찰할 수 있으며, 시효가 진행됨에 따 라 솔더내 공정조직은 결정립성장 및 $\mathrm{Ag}_{3} \mathrm{Sn}$ 의 금속간화 합물이 조대화되는 경향이 나타나고 있다. 솔더 접합계 면에서는 시효초기에 비하여 시효시간이 증가함에 따라 void가 점차적으로 커지는 경향이 나타났다.

Fig. 4는 시효시간에 따른 $\mathrm{Sn}-4.0 \mathrm{wt} \% \mathrm{Ag}-0.5 \mathrm{wt} \% \mathrm{Cu}$ 솔

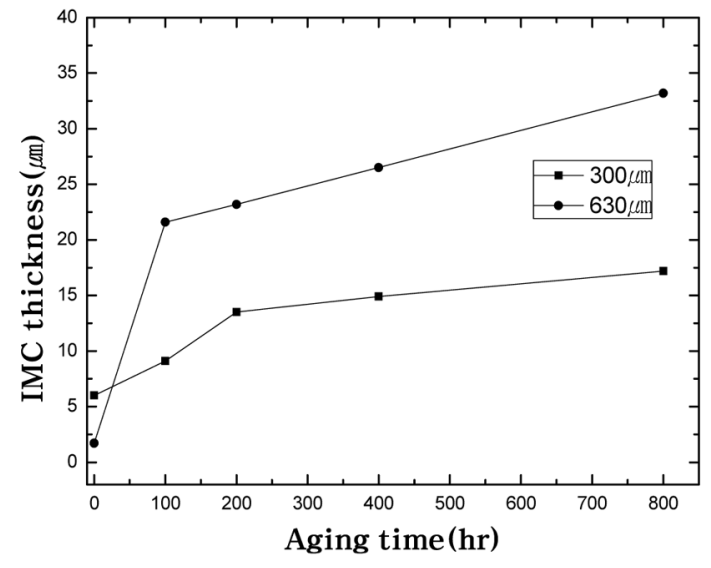

Fig. 4. IMC thickness for the interface between the Sn$4.0 \mathrm{wt} \% \mathrm{Ag}-0.5 \mathrm{wt} \% \mathrm{Cu}$ solder ball and substrate as a function of aging time.

더의 접합계면에 형성된 금속간화합물 층의 두께변화를 나타내었다. 솔더볼/UBM 계면에서, 시효시간이 증가함에 따라 금속간화합물의 두께가 증가하는 경향을 보이는데, 시 효초기에 두께가 급격히 증가하며 시효가 장시간 진행되 
는 동안에는 그 증가가 비교적 일정하였다. 직경 $630 \mu \mathrm{m}$ 솔더에서, 시효하지 않은 경우에는 $1.7 \mu \mathrm{m}$ 두께의 $\mathrm{Ni}_{3} \mathrm{Sn}_{4}$ 상이고, 시효시간이 $100 \mathrm{hr}, 200 \mathrm{hr}, 400 \mathrm{hr}$ 인 경우에는 $\mathrm{Cu}$ 의 확산에 의한 상변태가 진행되면서 각각 $21.6 \mu \mathrm{m}, 23.4 \mu \mathrm{m}$, $26.5 \mu \mathrm{m}$ 두께의 $(\mathrm{Cu}, \mathrm{Ni})_{6} \mathrm{Sn}_{5}$ 상으로 성장하였으며, 시효시간 이 800 시간인 경우에는 $33.2 \mu \mathrm{m}$ 두께의 $\mathrm{Cu}_{6} \mathrm{Sn}_{5}$ 상이 되 었다. 시효처리 온도에 비하여 높은 온도의 리플로우 과 정에서는 $\mathrm{Ni}$ 과 $\mathrm{Sn}$ 이 직접 반응하여 $\mathrm{Ni}_{3} \mathrm{Sn}_{4}$ 를 형성하지 만, 시효온도에서는 $\mathrm{Cu}$ 의 확산속도가 $\mathrm{Ni}$ 의 확산속도보다 빠르기 때문에 $\mathrm{Cu}$ 확산에 의해 $\mathrm{Cu}$ 화합물의 양이 증가하 는 것으로 생각된다. 직경 $300 \mu \mathrm{m}$ 솔더에서도 시효초기에 두께가 비교적 크게 증가하며, 시효시간이 $200 \mathrm{hr}$ 이상이 되면 두께는 완만하게 증가하였다. 시효하지 않은 경우는 $6 \mu \mathrm{m}$ 두께의 $\left(\mathrm{Cu}, \mathrm{Ni}_{6}\right)_{6} \mathrm{Sn}_{5}$ 상이고, 시효시간이 $100 \mathrm{hr}, 200 \mathrm{hr}$, $400 \mathrm{hr}$ 인 경우에는 $\mathrm{Cu}$ 의 확산에 의한 상변태가 진행되면 서 각각 $9.1 \mu \mathrm{m}, 13.5 \mu \mathrm{m}, 14.9 \mu \mathrm{m}$ 두께의 $\mathrm{Cu}_{6} \mathrm{Sn}_{5}+$ $\mathrm{Cu}_{3} \mathrm{Sn}$ 상으로 성장하였다. 솔더볼의 크기가 작을 때, 리플 로우 과정에서 비교적 큰 두께의 금속간화합물이 형성되 는 것은 솔더볼이 클 때에 비하여 열영향을 받는 면적이 상대적으로 증가하여 $\mathrm{UBM}$ 과의 반응이 활발해지기 때문인 것으로 생각되며, 시효시간이 $200 \mathrm{hr}$ 까지는 화합물의 형성 속도가 비교적 빠른것도 이것에 기인하는 것으로 생각된다.

열시효에 따른 솔더/UBM 접합계면에서의 미세조직변 화에 관련된 이상의 내용을 정리하면, 솔더볼/UBM 계 면에는 리플로우 과정에서부터 일정량의 금속간화합물이 형성되며, 시효시간의 증가에 따라 금속간화합물 상의 종 류와 양이 변화하고, 결정립 및 void의 크기가 커진다. 금속간화합물의 두께는 시효초기에는 급격히 증가하지만, 시간이 증가함에 따라 다소 완만하게 증가하는 경향을 보 인다. 솔더볼이 작은 경우(직경 $300 \mu \mathrm{m}$ )에서는 시효처리 전에도 다른 솔더계면에서 관찰되지 않는 $\left(\mathrm{Cu}, \mathrm{Ni}_{6} \mathrm{Sn}_{5}\right.$ 상 의 금속간화합물이 관찰되었고 두께도 비교적 두꺼운 상 태였다. 또한, $\mathrm{Cu} / \mathrm{Ni}$ 구조의 $\mathrm{UBM}$ 층이 열시효를 통하여 금속간화합물을 형성하는 경우, $\mathrm{Ni}$ 은 확산 barrier로서 작 용하며, 장시간 시효를 진행할 때 모든 솔더에서 $\left(\mathrm{Cu}, \mathrm{Ni}_{6} \mathrm{Sn}_{5}\right.$ 상의 금속간화합물은 $\mathrm{Cu}_{6} \mathrm{Sn}_{5}$ 상과 $\mathrm{Cu}_{3} \mathrm{Sn}$ 상으로 변태하 였다. 이는 고상 내에서 $\mathrm{Cu}$ 의 확산계수가 $\mathrm{Ni}$ 보다 높기 때문에, 시효가 진행될 때 $\mathrm{Ni}$ 화합물의 형성이 억제되 고 $\mathrm{Cu}$ 화합물의 형성이 촉진되는 결과로 해석된다.

다음에는 열시효 시간에 따른 금속간화합물의 성장과 솔더 접합부의 전단강도특성의 상관관계를 검토해 보고 자한다. 고상상태에서 급격한 금속간화합물의 성장은 부 피감소 및 격자변형에 의한 솔더/UBM 계면에서의 응력 생성을 야기시키므로 전단응력의 인가시 솔더접합부는 급 격히 취성파괴를 일으키게 된다. ${ }^{1,2,5,11)}$ 이러한 현상은 $\mathrm{Sn}$ 계 솔더내에서 솔더접합부의 내 충격성이 크게 감소할 것 으로 예상할 수 있고, 솔더 접합부의 신뢰성을 감소시키
는 것으로 보고되고 있다. ${ }^{1-6)}$ 본 연구에서는 전단시험을 실시하여 열시효에 따른 전단강도의 변화와 최대전단하 중점에서의 변위량 변화를 분석하였다.

Fig. 5 는 $\mathrm{Sn}-4.0 \mathrm{wt} \% \mathrm{Ag}-0.5 \mathrm{wt} \% \mathrm{Cu}$ 솔더볼의 전단시험시 얻어진 하중-변위 곡선을 나타낸 그림이다. 그림 (a)의 직 경 $630 \mu \mathrm{m}$ 솔더볼에서 시효처리를 하지 않은 리플로우 처리 상태 그대로의 시편에서는 전형적인 연성파괴의 곡 선을 보이고 있으나, 열시효에 따라 최대전단하중점에서 의 변위량은 급격히 감소하고, 변위량도 다소 감소하는 경향을 보였다. 그림 (b)의 직경 $300 \mu \mathrm{m}$ 에서도 시효처리 를 하지 않은 리플로우처리 상태 그대로의 시편에서는 직 경 $630 \mu \mathrm{m}$ 와 마찬가지로 연성파괴 곡선을 나타내며, 열 시효에 따라 최대전단하중 및 변위량이 감소하지만 직경 $630 \mu \mathrm{m}$ 의 경우에 비해서는 비교적 완만하게 감소하고 있 음을 알 수 있다. 이것은 열시효에 의해 $\left(\mathrm{Cu}, \mathrm{Ni}_{6} \mathrm{Sn}_{5}\right.$, $\mathrm{Cu}_{6} \mathrm{Sn}_{5}$ 등의 금속간화합물이 증가하고 $\mathrm{Sn}$-rich상의 조대 화, 기공의 형성 등이 복합적으로 작용하여 나타나는 현 상으로 보이나, 솔더볼의 크기가 작고 $\mathrm{UBM}$ 이 비교적 작 은 경우에는 금속간화합물의 내부에 형성되는 결함의 크 기도 작게 나타나기 때문인 것으로 사료된다.

Fig. 6 은 Sn- $4.0 \mathrm{wt} \% \mathrm{Ag}-0.5 \mathrm{wt} \% \mathrm{Cu}$ 솔더볼의 시효시간에
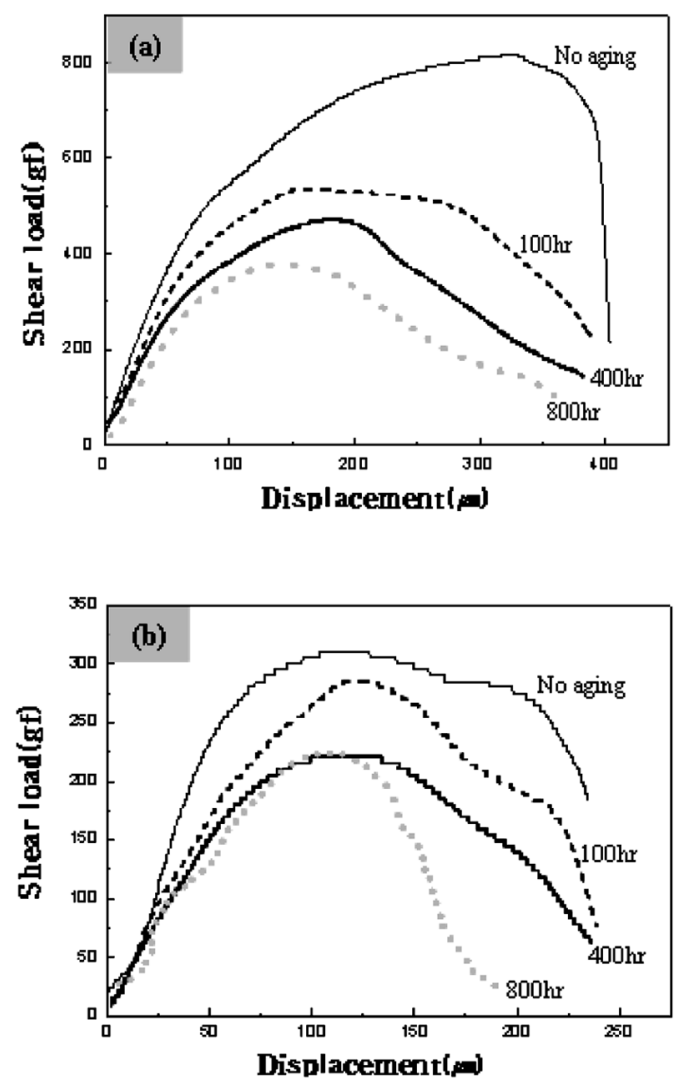

Fig. 5. Load-displacement curves for the Sn-4.0wt\%Ag$0.5 \mathrm{wt} \% \mathrm{Cu}$ solder ball with aging time: (a) $\phi 630 \mu \mathrm{m}$ and (b) $\phi 300 \mu \mathrm{m}$. 


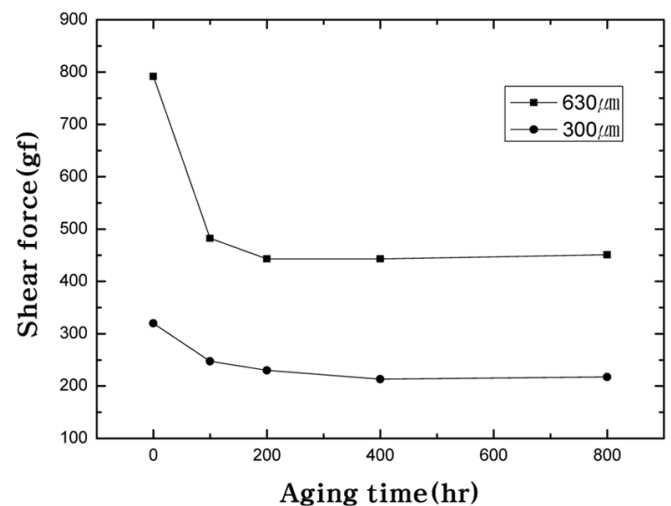

Fig. 6. Shear strength for the $\mathrm{Sn}-4.0 \mathrm{wt} \% \mathrm{Ag}-0.5 \mathrm{wt} \% \mathrm{Cu}$ solder ball with aging time.

따른 전단강도의 변화를 나타낸 그림이다. 직경 $630 \mu \mathrm{m}$ 솔더볼의 경우, 열시효에 의해 전단하중의 값이 급격히 저하하며, 시효시간 $100 \mathrm{hr}$ 이후에는 비교적 완만히 감 소하거나 비슷한 값을 유지하고 있다. 열시효에 의해 전 단강도값이 급격히 저하하는 것은 시효에 의해 $\mathrm{Ag}_{3} \mathrm{Sn}$, $(\mathrm{Cu}, \mathrm{Ni})_{6} \mathrm{Sn}_{5}$ 등의 금속간화합물이 증가하고 Sn-rich상이
조대화하며 void가 성장하여 취성이 큰 조직 상태가 됨 과 동시에, 솔더접합부에서 강도적 불균질부가 존재하게 되는 것이 그 원인으로 생각된다. $175^{\circ} \mathrm{C}$ 에서 $100 \mathrm{hr}$ 정 도만 유지해도 솔더접합부의 강도가 현저히 저하하며, 신 뢰성에 큰 손상을 초래하게 된다는 것을 알 수 있다. 직 경 $300 \mu \mathrm{m}$ 솔더볼의 경우는 솔더볼이 큰 직경 $630 \mu \mathrm{m}$ 의 경우에 비하여 접합강도가 약 2 배 정도 작다. 이것은, 같 은 조성일지라도 솔더볼의 크기 및 접합계면의 면적이 더 작을 뿐 아니라 계면에 형성되는 금속간화합물의 종류도 다르기 때문으로 생각된다.

전단시험시 최대전단하중에 대한 솔더접합부의 금속간 화합물과 그 파괴거동은 밀접한 관계를 가지고 있다. 금 속간화합물은 본질적으로 솔더재료보다 경하고 취약한 조 직이기 때문에 솔더접합부의 금속간화합물 부근에서 강 도적 불균질부가 존재하며, 이것은 전단시험 도중 접합 계면 부근 솔더의 소성변형을 야기시키면서 전단응력성 분을 생성하게 된다. 이때 생성된 금속간화합물 층에서 의 파괴거동을 관찰하기 위해서는 전단시험장치의 팁 위 치를 가능한 한 낮게 하는 것이 좋다.

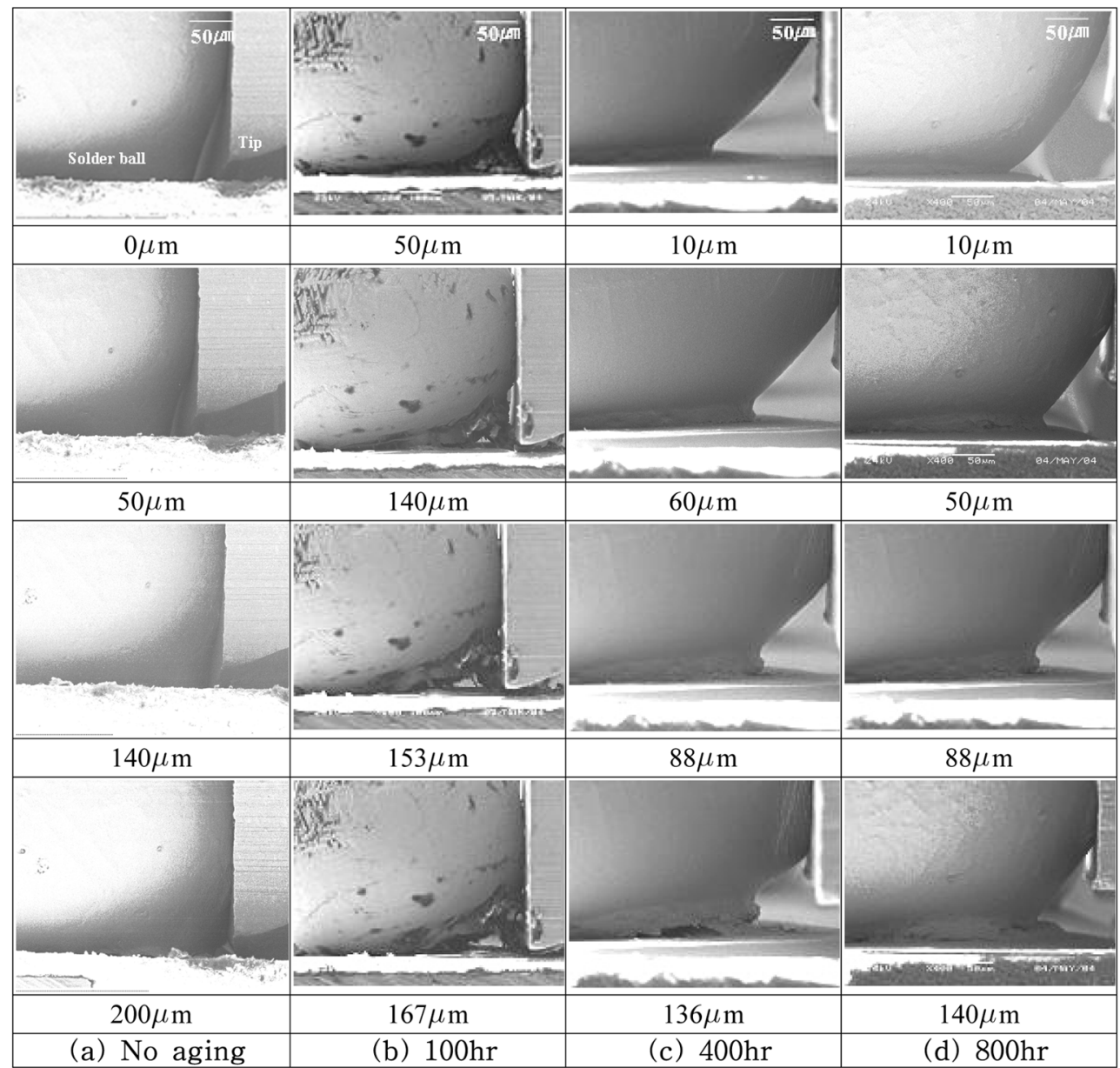

Fig. 7. SEM images for the micro-fractural behaviors at the interface between the $\mathrm{Sn}-4.0 \mathrm{wt} \% \mathrm{Ag}-0.5 \mathrm{wt} \% \mathrm{Cu}(\phi 630 \mu \mathrm{m})$ solder ball and substrate. 
Fig. 7은 SEM내 미소전단/굽힘시험장치를 이용하여 $\mathrm{Sn}$ $4.0 \mathrm{wt} \% \mathrm{Ag}-0.5 \mathrm{wt} \% \mathrm{Cu}$ (직경 $630 \mu \mathrm{m}$ ) 솔더볼을 전단시험하 는 도중, 솔더볼/UBM 계면에서의 미세파괴거동을 $\mathrm{SEM}$ 내에서 실시간으로 관찰한 결과이다. 시효처리 하지 않 은 솔더볼의 경우, 전단부하시 전단팁의 이동에 따라 솔 더볼/UBM 계면부에서 균열이 발생하여 접합계면을 따 라 전파되었다. 시효처리를 하지 않은 경우는 솔더내 파 괴인 연성파괴 경향을 보이지만 시효시간이 증가함에 따 라 작은 전단하중과 변위에서 균열이 발생하고 쉽게 전 파되는 취성적 파괴경향을 나타내었다. 균열발생은 시효 처리시에 형성된 금속간화합물과 솔더 소재 사이의 void 에서 시작되는 것으로 관찰되었으나, 균열의 발생 및 전 파가 매우 급격한 속도로 이루어지기 때문에 최소의 변 위속도하에서도 순간적인 실시간 포착은 곤란하였다. 전 단팁이 솔더볼에 전단하중을 부하해감에 따라 솔더볼/ $\mathrm{UBM}$ 계면에 존재하는 void의 크기가 점차 커지고, 응 력집중되는 부분에 균열이 발생되며, 이들 발생된 균열 이 서로 이웃하는 균열과 합체되면서 하중 작용방향인 접 합계면을 따라 확장되고 성장-전파해간다. 시효처리 시 간이 증가함에 따라 솔더/UBM 계면에서 neck가 형성되 고 성장하는 경향이 뚜렷해지며, 발생된 균열이 전파되 어 계면 전체로 확장될 때의 변위량이 점차적으로 감소 하는 경향을 보이고 있다. 이것은 상술한 전단시험 결과 에서, 금속간화합물의 성장 및 결정립 조대화에 따른 전 단강도 및 변위량이 감소하는 것과 잘 일치하고 있으며, 시효시간이 증가함에 따라 솔더/UBM 계면에 형성된 금 속간화합물을 통하여 균열이 쉽게 발생하기 때문인 것으 로 생각된다. 또한 시효시간이 증가함에 따라 균열전파 경로가 솔더의 내부방향으로 이동한 것을 볼 수 있다. 이 것은 시효시간이 증가함에 따라 취성이 큰 금속간화합물 의 두께가 두꺼워지고 솔더/UBM 계면 위까지 돌출되면 서 취약한 부분이 커지고, 이 부위가 응력집중을 받게 되 어 균열전파경로가 솔더 내부방향 쪽으로도 향한 결과에 기인하는 것으로 사료된다. 직경 $300 \mu \mathrm{m}$ 솔더볼의 경우, 접 합계면 부위에서 균열이 발생하여 계면전체로 전파되는데 에 소요되는 하중 및 변위량은 직경 $630 \mu \mathrm{m}$ 에 비해서 다 소 작아졌으나, 시효시간이 증가함에 따라 계면전체로의 균열전파에 이르기까지의 변위량 감소등 전체적으로 직경 $630 \mu \mathrm{m}$ 의 솔더볼과 유사한 파괴거동을 보였다.

\section{4. 결 론}

솔더볼/UBM 접합계면에는 리플로우 과정에서부터 일정 량의 금속간화합물이 형성되며, 시효시간이 증가함에 따라 금속간화합물의 종류와 양이 변화하였다. 또한 솔더볼의 크 기에 따라서도 형성되는 금속간화합물의 종류와 양, 변화 양상이 다르다. 시효시간의 증가에 따라 접합계면 부위에
서 void의 크기가 커지고 결정립조대화가 일어났다.

시효처리하지 않은 솔더볼/UBM 접합계면의 경우는 연 성파괴의 경향을 보이지만, 열시효에 의해 증가하는 금 속간화합물, void 증대 등의 영향으로 시효시간이 증가 함에 따라 취성파괴의 경향을 나타내며 전단강도도 급격 히 저하한다. 솔더볼 직경 $300 \mu \mathrm{m}$ 의 경우가 $630 \mu \mathrm{m}$ 의 경우에 비하여 열시효에 따른 전단강도의 저하가 비교적 완만하였다.

솔더볼/UBM 접합계면에서 균열발생은 접합계면에 존 재하는 void에서 일어나며, 이들 발생된 균열이 서로 이 웃하는 균열과 합체되면서 하중작용방향인 접합계면을 따 라 확장되고 성장-전파되어 간다. 시효시간이 증가함에 따라 균열의 발생 및 성장-전파속도가 빨라졌다.

\section{감사의 글}

이 논문은 정부(교육인적자원부)의 재원으로 한국학술 진흥재단의 지원을 받아 수행된 연구(R05-2003-000-11998 -0)이며, 이에 감사드립니다.

\section{참 고 문 헌}

1. Y. Y. Wei and J. G. Duh, J. Mater. Sci. Mater. El., 9(5), 373(1998).

2. S. Choi, T. R. Bieler, J. P. Lucas and K. N. Subramanian, J. Electron. Mater., 28(11), 1209(1999).

3. H. Oettel and R. Wiedemann, Surf. Coat. Technol., 76(1), 265(1995).

4. K. S. Ravichandran, Mat. Sci. Eng. A, 201(1-2), 269(1995).

5. D. R. Frear and P. T. Vianco, Metall. Mater. Trans. A, 25(7), 1509(1994).

6. K. H. Prakash and T. Sritharan, Acta Mater., 49(13), 2481(2001).

7. G. Ghosh and M. J. Pfeifer, J. Electron. Mater., 30(9), 1145(2001).

8. J. W. Yoon, C. B. Lee and S. B. Jung, Mater. Sci. Technol., 19(8), 1101(2003).

9. D. R. Flanders, E. G. Jacobs and R. F. Pinizzotto, J. Electron. Mater., 26(7), 883(1997).

10. M. McCormack, S. Jin, G. W. Kammlott and H. S. Chen, Appl. Phys. Lett., 63(1), 15(1993).

11. W. Yang and R. W. Messler, J. Electron. Mater., 23(8), 765(1994).

12. B. S. Chiou, K. C. Liu, J.-G. Duh and P. S. Palanisamy, IEEE. Trans. CHMT, 13(2), 207(1990).

13. Y. Wang and K. N. Tu, Appl. Phys. Lett., 67(8), 1069(1995).

14. S. H. Lee, B. W. Park, J. H. J and D. Kwon, in Proceeding of the Tenth Conference on Mechanical Behaviors of Materals (Ansan, Korea, October 1996) P.521.

15. C. J. Chen and K. L. Lin, J. Electron. Mater., 29(8), 1007(2000). 